\title{
Transnational history. What lies behind the label? Some reflections from the Early Modernist's point of view ${ }^{1}$
}

\author{
Bartolomé Yun Casalilla \\ Pablo de Olavide University, Carretera de Utrera, Km 1. 41013, Sevilla (España) \\ e-mail: byuncas@upo.es
}

\begin{abstract}
Submitted: 3 September 2014; Accepted: 17 October 2014
ABSTRACT: This essay presents the transnational approach to history from an early modern historian's perspective. It starts with a short historiographical review of the recent trends in this field, showing how the transnational approach has been used predominantly in the study of contemporary history. Distancing itself from purely terminological debates, the essay discusses how the transnational approach can also be contextualized as a tool to understand pre-modern European societies or, by extension, the history of societies that do not fit the modern notion of the nation and are not organized as nation states, emphasizing the heuristic possibilities of this approach. The essay concludes by recalling some important contributions made from this perspective, even when their authors do not use the term "trans-national".
\end{abstract}

KEYWORDS: transnational history; entangled history; methodology and approach; comparative history; nation; nation state; imagined communities; early modern history.

Citation / Cómo citar este artículo: Yun Casalilla, Bartolomé (2014). "Transnational history. What lies behind the label? Some reflections from the Early Modernist's point of view". Culture \& History Digital Journal, 3(2): e025. doi: http://dx.doi.org/10.3989/chdj.2014.025

RESUMEN: Historia transnacional. Qué hay detrás de la etiqueta? Algunas reflexiones desde la perspectiva de un historiador de la época moderna.- Este ensayo es un intento de analizar las posibilidades de la historia trans-nacional desde la perspectiva del historiador de la época moderna. Se realiza en primer lugar una breve aproximación historiográfica al desarrollo reciente de esta disciplina llamando la atención sobre el modo en que su uso se ha concentrado sobre todo entre los historiadores de la época contemporánea. En un intento de distanciarse de debates puramente terminológicos, se discute a continuación el modo en que esta perspectiva analítica nos puede ayudar a entender las sociedades de la época moderna europea o, por extensión, la historia de sociedades en las que los conceptos actuales de nación y estado nacional no articulan las formas de organización política. Se trata de este modo de subrayar el valor heurístico de esta perspectiva analítica. Se termina recordando las importantes contribuciones realizadas desde esta perspectiva al conocimiento de la historia moderna incluso cuando el término tras-nacional no es ni siquiera utilizado por sus autores.

PALABRAS CLAVE: historia trans-nacional; historia entrelazada; metodología y perspectivas analíticas; historia comparada; nación; estado nación; comunidades imaginadas; historia moderna.

Copyright: (C) 2014 CSIC This is an open-access article distributed under the terms of the Creative Commons AttributionNon Commercial (by-nc) Spain 3.0 License.

Since the first years of this century, the terms transnational and transnational history have become progressively more familiar to historians. There are expressions such as "transnational turn", coined by Akira Iriye, which clearly reflect the increasing relevance of this concept (Iriye, 2007). Curiously enough, however, the term trans- national is usually reserved for modern western societies in which the nation state composes the main scenario of research. Christof Bayly (2006) has even shed some doubts about the possibilities of a transnational history for the period before the $19^{\text {th }}$ century. Furthermore some journals — such as the electronic H-Soz-u-Kult, edited in 
Germany - have devoted special numbers to transnational history, in which studies on the early modern period, rightly or not, have been absent. ${ }^{2}$ Over the last decade and again, with or without reason, many books with no chronological specification seem to take for granted that transnational history is exclusively concerned with - and confined to - the nineteenth and twentieth centuries. ${ }^{3}$

The purpose of this brief contribution is to show the intellectual roots of what we today call transnational history as well as to discuss the concept and its methodology as a way to assess how and why this is also becoming a trend of special interest for early modernists. It is not my intention to go into a terminological debate - on the contrary - or to make a strong terminological point proposing the use of the term when talking about pre-modern societies. But I do want to invite some reflection on the need to consider current historiography on early modern Europe when speaking of transnational history. My starting point is a presumption that I hope is acceptable and that some historians have already proposed: when we speak of transnational history, we are not referring to a method, but to an approach, a viewpoint that allows us to discover new dimensions of the past or reassess and, if necessary, criticize previous ideas on previous interpretations of it. ${ }^{4}$

\section{ON THE UBIQUITY OF TRANSNATIONAL HISTORY}

Today we have journals and forums on the web claiming to promote transnational hi story. To my knowledge, a pioneering one is the history.transnational, created in 2004 by the Centre of Advanced Study at the University of Leipzig and by the "Transfer culturels" research group at the Centre National de la Recherche Scientifique in Paris. ${ }^{5}$ Many others have followed in the wake of this initiative, such as The Journal of Transnational American Studies, launched in 2008. ${ }^{6}$ A glance at the web is enough to see the openings of Chairs in Transnational history and it is not uncommon to see many types of academic and scientific events or research centers which are termed as transnational in focus and nature. In a monograph number published by the Journal of American History as early as 1999, we find articles on: transnational perspectives on the history of the United States; on the ways of writing transnational history, on Atlantic History, etc. (Va.Aa., 1999). There even exists a dictionary on transnational history like the one which has been produced by the very same Akira Iriye and Pierre-Yves Saunier (2009). Such a project is an excellent example of the ubiquity of transnational history. Just a glance at the entries that the authors are developing reveals that it is possible to speak of the transnational history of many different realities. The relevance of transnational history, often connected to comparative history, has increased among historians. Not only regular publications and research centers, conferences and workshops but also summer schools such as those taking place in Berlin, Florence or Paris, etc. have demonstrated the vitality and scope of this area of research in many different countries and academic milieus.
Nevertheless and maybe because of the ubiquity of the term and the way in which the term is often used, the meaning of it is not so clear. What do we refer to when we use these magic words? Is it possible to trace their history? Though answering these questions in full would obviously deserve a particular type of research, one could say that the word "transnational" has two different roots among historians.

On the one hand, it is a concept - even though the term is not always used - which was very much present among those German and French historians of the 1990s who were interested in the cultural transfers between Germany and France, particularly during the $18^{\text {th }}$ century. ${ }^{7}$ The emerging idea was that the cultural history of the two countries was strongly intertwined and that mutual influences had been crucial for the definition of the two national cultures and national states. This also means that the transnational approach was linked to the concept of cultural transfer, as well as to the notion of entanglements which from then onwards would be inherent in the idea of transnational history.

On the other hand - and with no initial apparent connection to the German-French historians - the word "transnational" also appeared at the beginning of the 90s in some discussions taking place in the US and, in particular, within the pages of the most influential historical journal of that country, that is, the American Historical Review, which devoted a special number to this approach in $1991 .{ }^{8}$ There I. Tyrrell and others launched a debate aiming at understanding the history of the USA from a transnational perspective, an expression the meaning of which was rather different from that employed in the German-French context. For some of these scholars transnational history was associated with comparative history and it was a way to combat the so-called American exceptionalism. Transnational comparisons - that is comparisons of North American history with those of other countries and empires - were a way to break the many stereotypes and simplistic assumptions that were very much present in the US historical narrative at the time. But the term was also used to emphasize the need for a history without the nation state.

A simple glance at the publications produced by these two groups of historians give the impression that for some years they wrote without a strong knowledge of one another. In fact, a major step forward was made when German and French scholars started talking about entangled history and histoire croisée as a complement of - and for some like Michel Espagne as a substitute forcomparative history. The idea was that, given what they considered to be the insuperable difficulties of comparing interlinked realities, it would be better to open a different approach aiming at analyzing the common relations between those realities. ${ }^{9}$ And this almost coincided with another important development taking place again in the pages of The American Historical Review (2006), where the by-now flourishing debate on transnational history was held among specialists on modern and contemporary history, but where we hardly find any reference to the German-French tradition (Bayly, 2006). We know that 
there have been some cross-fertilization during the last years, ${ }^{10}$ but it is nontheless quite significant that for more than one decade there was a lack of mutual explicit reference, which is even more surprising in what is, by definition, an international field of study.

There are not only academic and scientific reasons for this flowering of research. As some authors have stressed (for example Thelen and Akira Iriye), there are also "external" causes for it. ${ }^{11}$ And these factors may offer an explanation for the disparate roots of the movement. The crisis of the nation state and the increasing criticism of historians of the conceptual framework of the nation state as a unit for the analysis of the past have opened the floor for an approach that is sometimes presented as an alternative. The globalization process, which obliges us to understand the past in a context broader than the nation or the nation state, has had similar effects.

\section{DEFINING TRANSNATIONAL HISTORY}

It is not easy to find a clear and universally accepted definition of transnational history. Akira Iriye, one of the most relevant and innovative practitioners, gave a very simple one almost ten years ago: "transnational history may be defined as the study of movements and forces that cut across national boundaries." (Iriye, 2004: 213) But is this enough? Of which national boundaries are we talking about? Nation state boundaries? Would it not be a too narrow definition which excludes pre-modern and nonWestern experiences? Perhaps due to the fashionable character of the term, this is quite a poly-semantic word of rather burred contours. For example, what are the semantic and conceptual differences between transnational and global history? Are these differences simply a matter of the spatial and cultural distance between the national borders we study? Today one can read competing ideas, - often mutually exclusive - that global history is a way to do transnational history; that a transnational approach is the only way to do world history. ${ }^{12}$ Sometimes transnational history is closely linked with Trans-Atlantic history and often one has the feeling that the concept is defined in the negative: a type of history whose main aim is to replace the so called old-fashioned national histories.

Thus it seems rather difficult to give an empirical and inductive definition. But one would say, to begin with, that unlike comparative history, which clearly implies a strong methodological proposal, transnational history should be considered as a way of approaching the past or even sometimes as a way of emphasizing a particular aspect of it. Transnational history is more a viewpoint than a method endowed with sophisticated, specific and exclusive tools of analysis. It is a perspective that historians adopt to discover new dimensions of new or old subjects. It can also be a way to revise common assumptions among scholars and to contextualise the local - even, sometimes, to analyze the local — in a wider and even, sometimes, global context (Yun, 2007).

Secondly, I would propose that when using the term transnational we are trying to emphasize an approach to history which underlines the ideological, cultural, economic and social entanglements between different people belonging to or located in different imagined communities in the widest and original sense of the term, that is, a set of people who perceived themselves as pertaining to the same community. An imagined community in this sense can be defined as a nation in the modern meaning of the world, but it is not necessarily the case. On the contrary, and taking some of the elements that B. Anderson used to define it, one could consider language, religion, ethnicity, the perception of a common past and traditions as possible variables to define that community even if it is not a nation in the modern sense of the term (Anderson, 2006 [1983]).

Considering all this, transnational history might be defined as an approach to the past which privileges the analysis of exchanges and mutual transfers across borders, be they political, religious, ethnic, etc. ${ }^{13}$, and which is concerned with mutual perceptions and with cross-national social relations and migration movements. Those historians who claim to practice transnational history mainly emphasize the study of the international institutions - labor organizations, multinational firms and more recently NGOs, etc.- of social and kinship networks spread among different countries, of diasporas and migrations, often understood not only as demographic phenomena, but also from the point of view of their internal social and cultural links and their intertwining with the different host societies. Cross-national and cross-cultural biographies are also a way to do transnational history. The cross cultural ideological and religious encounters and the exchanges of knowledge or of cultural practices between different social groups is, no doubt, another excellent example of a sort of transnational history which is very well represented in a number of studies. It is selfevident that - like the comparative method or even more than it - transnational history is not an entirely new phenomenon, as many of its practitioners acknowledge. Classics such as Braudel's Civilisation Materielle et Capitalisme, can be considered as illustrations of this approach (1979). Braudel is not the only example that we might quote.

\section{WHY AND WHAT FOR? ON THE METHODS AND INNOVATIVE POTENTIAL OF TRANSNATIONAL HISTORY}

Therefore, why? Why should we practice transnational history nowadays? What can be said in its favour? One should start by saying that both the term and the approach involve some danger.

One of them was identified some years ago by McGerr (1991). In doing transnational history, current historians are in danger of losing contact with the public. The argument is, at least apparently, solid. Since much of the public debate and politics is framed by current "national" problems, the separation between the transnational historian and the public could be a side effect of the development of transnational history. However, this view does 
not consider that today's public debate is becoming more and more transnational and global per se. Nowadays policy and political programs are not disentangled from cross-border problems. Just to give one pertinent example, terrorism, a very important concern in today's societies, cannot be understood or fought from a purely national perspective. The public is aware of this to the extent that it asks for transnational action and cooperation as the only way to extinguish it. The same could be said on the increasing importance in the public debate of the relation between different cultures and civilizations or on the ecological problems and the propagation of illnesses and diseases. As in the case of many other current problems, what we all think and what we all take as a reference for our political decisions is the ability of the different governments to create the necessary transnational links that can lead to the resolution of these problems. Rather than being a diversion that can distance historians from current debates and social concerns, transnational history is a way to enhance communication between them and the public.

Paradoxically, another critique of transnational history is that it could reinforce even more nationalistic approaches and even revive the worst elements of them. It is true that a possible side effect might be that the historian adopts an essentialist approach to the history of nations, considering them as fixed, static, closed and independent frozen entities always in confrontation over the course of centuries. Yet it is important to note that this is not a specific danger of transnational history. Historians have been fighting, and in some countries still are, with this view of the past whether or not they promote transnational history. Furthermore, transnational history can be a good antidote if we agree that what defines those communities and, consequently, the borders between them is not always the idea of belonging implicit in the nineteenth-century western concept of nationhood and that the content and the way that the idea of belonging is shaped is something to be discovered by historians, in many cases by applying an entangled or histoire croisée approach. What is needed, in other words, is a generic definition of the sense of identity held simultaneously by early modern communities, regardless of the national programmes that they adopted, or had imposed upon them, many centuries later; the basis of this approach is that many distinct communities may have shared perceptions of their own traditions and self and that what came later - in the nineteenth or twentieth centuries, when peasants were turned into Frenchmenhinders and obscures the attempt to understand these early modern projections. Those communities can be defined by the intersections of criteria of language, religion, ethnicity, the idea of belonging to the same natural community (patria), etc. We could even say that the study of these communities from an avant la lettre trans-"national" perspective is a way to understand their relations before the adoption and imposition of the modern western concept of nationhood and that, by doing so, the historian can also comprehend how the interaction among those communities led them to think of themselves as separate na- tions and nation states. As Christoph Conrad has said, it is always possible to envisage a "national historiography as a transnational object" (Conrad, October 2004). Thus, the rise of the very same nation state can be understood as something not necessarily linked to a single, eternal and frozen reality, but as a historical product whose internal diversity and contingency are crucial. Today's nations can be also seen as something full of mutual interferences, as a result of cross-fertilization and processes of rivalry and even warfare, which meant that national characteristics and identity were constantly redesign by cross-boundary relationship.

Moreover, this is a danger that can be counterbalanced by correctly using the methods of transnational history. It is precisely in those methods where one should look for the originality and justification of a "new" transnational history. As I said before, many historians agree that transnational history is rather an approach than a methodology. But what about the methods for this approach? My own proposal is that entangled history and histoire croisée be considered a methodological corpus for the analysis of the past, which together with network analysis constitutes a method for transnational approaches. In fact, the combination of these two tools - entangled history and network analysis - enhances and systematizes the study of the interconnections and interaction between different realities or social groups. ${ }^{14}$ They both claim to offer an analysis of such relations by focusing on the agents involved in them and by putting the accent on the mediators between different historical units. Both imply a clear definition of the units whose relations must be considered in each moment and in each case. They both also put a strong accent on the processes of reception, adoption and "social translation" and rejection of cultural values, goods and social influences between different societies and social groups.

This outlook is precisely what in my view can lead to a "new" and more vigorous transnational history. As in the comparative method, the transnational approach is enhanced by a more systematic and explicit use of this conceptual tool; that is, by a more careful definition of the units of comparison or, in the case of a transnational approach, by a more explicit consideration of the mediators and the links between different realities. Needless to say, neither entangled history nor network analysis are exclusive to transnational history. On the contrary, we could use their methodological tools for analyzing units and realities embedded in the same imagined communities. But it is self-evident that they compose the best instrument to understand the relations between those imagined communities in any time and space.

The use of these analytical tools leads to some requirements that are essential for a more accurate and sophisticated transnational history. The need to emphasize the notion of historical context is one of them. If reception, adoption or adaptations and rejection are key concepts, the social, economic, political or ideological reality in which those processes are embedded is just as crucial. This differentiates the new transnational history from many previous studies. A transnational approach to inter- 
national trade implies, for example, that the historian not only considers flows of commodities and money, but also how those flows changed the societies involved in that particular relationship.

Also the new transnational approach should mean a careful consideration of the right level of mediation and of the agency in the relationship between the units under study. It should pay attention to the mediators, to their particularities and the way they played their role, to their internal mechanisms and to the way these had an effect on the exchange. It should start from the idea that mediators are not innocuous at all. They can even change the message and the nature of the relations between different societies. To continue with our example of international trade, the role of merchant networks could be also part of this approach, as well as the way those networks are built, their religious, cultural or social bases and their internal functioning, etc.

As a consequence of the complexities involved in the process of reception and transmission, transnational history is not necessary interdisciplinary, but it tends to be so. Furthermore, cultural history, today in vogue, is an integral part of transnational history, as long as cultural change is always an outcome of the interactions between different societies. The way that change is embedded in - or accompanies - social and economic transformations is also an essential problem for transnational historians. Transnational history is not necessarily cultural history, but cultural history is often a very important ingredient of transnational history.

\section{A TRANS-"NATIONAL" HISTORY OF EARLY- MODERN SOCIETIES?}

Defined in this way, it is possible to speak of a transnational history without nation states or, indeed, before the nation states. Or, to put it differently, it is possible to envisage a transnational approach to societies in which the "nation" is not associated with its modern form, usually linked to the concept of nation state and the modern idea of citizenship.

To begin with, it is obvious that when historians are speaking of a transnational history for societies in which the nation state does not exist, they are making a petition of principle: to speak of the "nation" in the widest or in its non-western modern sense, and to put the emphasis on the idea of a community whose historical distinctiveness is to be explored. It also means that for some societies -i. e. early modern European societies - the term "nation" has to be contextualized and sometimes used in a more general way, or even substituted by other more historical concepts, like patria, the set of people who share a feeling of group due to birth. But it is clear that a lato sensu transnational history is possible for the period and societies where the nation state was not a historical reality and, therefore, that it is possible to speak of a sort of trans-"national" history for western societies in the early modern period, as long as we decide not to discuss labels and to reach a functional agreement on the general terminology.
The immediate and very logical question, however, is why not to use the term entangled or connected history, much more neutral in connotation and in some way less risky than transnational. ${ }^{15}$ As I said, it is not the aim of this article to discuss terminological questions. Furthermore, entangled history has also become a pervasive term which refers to the study of connections and interactions among different societies, But I would say that trans"national" has some other advantages. The most important one in my view is that, though controversial in this sense, it refers to - and makes a very explicit plea forthe study of the effects of those interconnections in the communities whose entanglements are analyzed. It also underlines in a more explicit way the acknowledgment of the borders between these societies, that is, the variety and differences between the communities under study. In this sense, also the advantages in regard alternative concepts such as cross-border history, possibly another very good alternative, seems to be obvious, since this term, again, puts the accent on the separation and the division line between two imagined communities.

The possibilities of this approach, whatever term we use, on the other hand, are evident if we look at the historiographical panorama, since many of the requirements of transnational history are very much present in the early modernist's research agenda. Cultural history in practice has been strongly fertilized by this approach, to the extent that it is present even among the historians of other fields, including economic history. A variety of it - such as the history of consumption - can be taken as proof of this development. Studies such Maxine Berg's work on the introduction of Asian porcelains in eighteenth century England and the import substitution process that it provoked are an excellent example on how global trans-"national" connections and the interaction of different consumption patterns can lead to crucial economic changes in which cultural processes played a very important role (February 2004). Books such as those of Nützenadel and F. Trentmann (2008) or Brewer and F. Trentmann (2006) are very explicit on the way the circulation of products from one area of the word to another can determine changes in consumption patterns of many other regions in the world. ${ }^{16}$ We also have instances of research with a very interdisciplinary approach in which intercultural exchanges of a variety of goods among different areas of the world have been studied from the economic, social, cultural and even intellectual perspectives, considering not only the adoption and the mediators in these exchanges but also processes of rejection and strong hybridization. ${ }^{17}$

It could be said, with some justification, that all of these examples are rather in the field of global history than that of transnational studies, but many other more intra-European illustrations might be cited. In the field of the social history of elites we have outstanding examples of how cross-border aristocratic networks have been studied to understand the history of very prominent and influential families. ${ }^{18}$ Likewise, recent research has put the emphasis on these international connections and the role of mediators while some authors have used the term 
"mixed nobilities" to refer to the cross-boundary practices of very important sections of pre-modern European elites. ${ }^{19}$ Diplomatic history, a field in which the transnational approach has proved to be very fertile for modern historians, is becoming a booming field for the trans"national" history of the early modern times. The role of ambassadors as cultural mediators, the uses of symbolic diplomacy, the way it affected international relations and many other aspects, today constitute a very important part of the early modern historian's agenda whatever the term - transnational or not transnational - we use to refer to it. ${ }^{20}$ These aristocratic networks have their counter-examples in the international merchant networks and diasporas or cultural exchanges, very well known in European history decades ago. ${ }^{21}$ The examples in the field of cultural exchanges in general are also very expressive of the enormous potential of this approach. ${ }^{22}$

Not everything, then, is entirely new and the term transnational can be controversial when applied to early modern societies. But it is quite possible that, independently of the answer to the terminological petition of principle that we mentioned above - and which is not the crucial point in my view-, the only condition for a good trans-"national" approach to early modern societies lies in the way we focus on mediators, networks, adoption and adaptation, and in some cases rejection, when studying the interlinking factors among different societies, as well as to the extent to which we are able to make visible new aspects and dimensions of those societies. The advantage of the transnational approach lies, therefore, in the heuristic value it brings to our research, the type and variety of questions it provokes and the methods it obliges us to use. There is no doubt that, if the methods are well used, this is going to be an invaluable tool for the writing of history in the future.

\section{NOTES}

1. The core ideas of this text were presented and discussed several times at the Summer School on "Comparative and Transnational history" held at the European University Institute, Florence, since 2005 until 2012. I would like to thank some of my colleagues who gave ideas and criticism on it and very much in particular to Gerhard Haupt, Antonella Romano, Kiran Patel, Pavel Kolar, Luca Molà and Steve Smith. Since the first years of that Summer School, the explosion of transnational history has been more than evident and the number of publications in the field - many times even without using the label— have dramatically increased. It is not the intention of these pages to quote all this material, but only to make some reflections which are still very much present among historians and that I found interesting for the readers of Culture and History. I also want to thank Phillip Williams for his help with the English version of this article.

2. See http://hsozkult.geschichte.hu-berlin.de/forum/id=875\&type= diskussionen (Consulted 24 Octobre, 2014).

3. See in example A. Iriye (2012), or from a different tradition, H. G. Haupt and J. Kocka (2009).

4. This is also the opinion of many practitioners of transnational history, see in example Bayly (2006). By the same year, I expressed the same idea in Yun-Casalilla (2007).

5. http://gesi.sozphil.uni-leipzig.de/publications/geschichtetransnational/ (Consulted 24 Oct. 2014)
6. http://www.theasa.net/journals/name/journal of transnational american_studies/ (consulted 24 Oct. 2014)

7. See among others, M. Espagne and M. Werner (1988), M. Espagne (1995 and 1999), or H. E. Bödeker and E. François (1996), or M. Werner and B. Zimmermann (2002). This same historiographical process can be seen in the collection of works at $<\mathrm{http}: / /$ www.het.org/ german/discuss/Trans/forum_trans_index.htm $>$ (Consulted the 31 December 2006).

8. See the different opinions of Ian Tyrrell, and Michael McGerr (Tyrrell 1991 and 1991b; McGerr 1991).

9. The methodological grounds were established in works such as Michel Espagne (1994). Some reflections on the bases of transnational history from the perspectives of "histoire croisée", see M. Werber y B. Zimmermann (2004). Also J. Kocka (February 2003).

10. The introduction of H. G. Haupt and J. Kocka to the volume Comparative and transnational history: Central European approaches and new perspectives (2009) is very meaningful.

11. See mainly Akire Iriye (2004).

12. The very same Akira Iriye has referred to the overlapping but different nature of global and transnational history in an assertion which is impossible to refute: "The distinction between global history and transnational history, to be sure, was often tenuous and remains so." (2012: 11)

13. It is not strange, and I wish to express my agreement with her, that Mae N. Ngai has nuanced and open the definition by saying that transnational history "follows the movement or reach of peoples, ideas, and/or things across national (or other defined) borders" "Promises and perils of transnational history" in Perspectives on History (December 2012). http://www.historians. $\mathrm{org} /$ publications-and-directories/perspectives-on-history/december-2012/the-future-of-the-discipline/promises-and-perilsof-transnational-history (consulted 27 October, 2014).

14. See among many others, M. Werber and B. Zimmermann (2004).

15. Though the terms entangled or connected history have also become very common among historians, the logical reference here is to some of the works produced by S. Subrahmanyam (2005 and 2005b).

16. In the same line and among many others, K. Kupperman (2012). An excellent state of the art from the Atlantic history perspective, can be found in E. H. Gould (June 2007).

17. That is the central point of B. Aram and B. Yun Casalilla (2014).

18. See in example J. Spangler (2009), S. Kmec (2010), B. YunCasalilla (2008), B. M. Lindorfer (2009), A. Terrasa (2009), A. Becucci (2011), and N. Monteiro (2009).

19. The term comes from A. M. Rao and S. Supphellen (1996). The role of mediators, though not always in a cross-border dimension, has been specialy emphasized in H. Cool, M. Keblusek and B. Noldus (2006).

20. Some good examples in H. Droste (2006), M. J. Levin (2005), T. J. Dandelet (2001), and H. Scott and B. Simms (2007).

21. Though written some years ago, the reader can find a state of the art on the roots of this trend in A. Molho and D. Curto (2003).

22. For only a prominent example, see the four volumes of Cultural Exchanges in Early Modern Europe (Va.Aa., 2007).

\section{REFERENCES}

Anderson, Bennedict (2006 [1983]) Imagined communities: reflections on the origin and spread of nationalism. Verso, London / New York.

Aram, Bethany and Yun Casalilla, Bartolomé (editors) (2014) Global Goods and the Spanish Empire, 1492-1824. Circulation, Resistance and Diversity. Palgrave MacMillan, Basingstoke.

Bayly, Christof (2006). "AHR Conversation: On Transnational history". The American Historical Review, 5: 1441-1464.

Becucci, Alessandra (2011) The Art of Politics and the Politics of the Arts. Francesco Ottavio Piccolomini: A case of Patronage 
in Thirty Years War Europe. (PhD defended at the EUI, unpublished).

Berg, Maxine (February 2004) "In Pursuit of Luxury: Global History and British Consumer Goods in The Eighteenth Century". Past and Present, 182: 85-142.

Bödeker, Hans E. and François, Etienne (editors) (1996) Aufklärung/ Lumières und Politik Zur politischen Kultur der deutschen und franzöisischen Aufklärung. Leipziger Universitätsverlag, Leipzig.

Braudel, Fernand (1979) Civilisation matérielle, économie et capitalisme : XVe-XVIIIe siècle, 3 Vols. Armand Colin, Paris.

Brewer, John and Trentmann, Frank (editors) (2006) Consuming Cultures, Global Perspectives. Historical Trajectories, Transnational Exchanges. Berg, Oxford-New York.

Conrad, Christof (October 2004) "National historiography as a transnational object". Representations of the Past: The writing of National Histories in Europe. Newsletter 1: 3-5.

Cool, Hans, Keblusek, Marika and Noldus, Badelock (editors) (2006) Your Humble Servant. Agents in Early Modern Europe. Uitgeverij Verloren, Hilversum

Dandelet, Thomas J. (2001) Spanish Rome, 1500-1700. Yale University Press, New Haven.

Droste, Heiko (2006) "Diplomacy as means of cultural transfer in early modern times". In Scandinavian Journal of History, 31, 2: 144-150.

Espagne, Michel (1994) "Sur les limites du comparatisme en histoire culturelle" In Genèses, 17: 112-121.

Espagne, Michel (editor) (1995) L'Ecole normale supèrieure et Allemagne. Leipziger Universitätsverlag, Leipzig.

Espagne, Michel (1999) Les transferts culturels franco-allemands. Preses Universitaire de France, Paris.

Espagne, Michel and Werner, Michel (editors) (1988) Transferts: les relations interculturelles dans l'espace franco-allmand (XVIIIe et XIXe siécle). Editions Recherche sur les Civilisations, Paris.

Gould, Eliga. H. (June 2007) "Entangled Histories, Entangled Worlds: The English-Speaking Atlantic as a Spanish Periphery". The American Historical Review, 112, 3: 764-786.

Haupt, Heinz G. and Kocka, Jurgen (2009) Comparative and transnational history : Central European approaches and new perspectives. Berghahn Books, Oxford and New York.

Iriye, Akire (2004) "Transnational History". Contemporary European History, 13, 2: 211-222.

Iriye, Akira (2007) "The Transnational Turn". Diplomatic History, 31, 3. 373-376.

Iriye, Akira (2012) Global and Transnational History: The Past, Present, and Future. Palgrave MacMillan, Basingstoke and New York

Iriye, Akira and Saunier, Pierre-Yves (2009) The Palgrave dictionary of transnational history. Palgrave MacMillan, Basingstoke and New York.

Kmec, Sonja (2010) Across the Channel: Noblewomen in Seventeenth-Century France and England: A Study of the Lives of Marie de La Tour, 'Queen of the Huguenots', and Charlotte de la Trémoïlle, Countess of Derby. Kliomedia, Trier.

Kocka, Jurgen (February 2003) "Comparison and beyond". History and Theory, 42: 39-44.

Kupperman, Karen (2012) The Atlantic in World History. Oxford University Press, New York and Oxford.
Levin, Michael (2005) Agents of Empire. Spanish Ambassadors in Sixteenth-Century Italy. Cornwell University Press, Ithaca and London.

Lindorfer, Bianca (2009) Cosmopolitan Aristocracy and the Diffusion of Baroque Culture: Cultural Transfer from Spain to Austria. (PhD defended at the EUI, unpublished).

McGerr, Michael (1991) 'The Price of the "New Transnational History". The American Historical Review, 96,4: 1056-1067.

Molho, Anthony and Curto, Diogo (2003) "Les Réseaux Marchands à l' Epoque Moderne”. Annales HSS, 58: 569-579.

Monteiro, Nuno (2009) "A Circulação das Elites no Império dos Bragança (1640-1808) Algumas Notas”. Tempo, 27 : 65-81.

Nützenadel, Alexander and Trentmann, Frank (editors) (2008) Food and Globalization. Consumption, Markets and Politics in the Modern World. Berg, Oxford and New York.

Rao, Anna. M. and Supphellen, Steinar (1996) "Les elites de pouvoir et les territoires "dépendents"'. In Les elites du pouvoir et la construction de l'État en Europe, directed by Reinhard, W., Presses Universitaires de France, Paris, pp. 102-131.

Scott, Hamish. and Simms, Brendam (editors) (2007) Cultures of Power in Europe during the Long Eighteenth Century. Cambridge University Press, Cambridge.

Spangler, Jonathan (2009) The Society of Princes. The LorraineGuise and the Conservation of Power and Wealth in Seventeenth-Century France. Ashgate, London.

Subrahmanyam, Sanjai (2005a) Explorations in connected history : from the Tagus to the Ganges. Oxford University Press, New Delhi and Oxford.

Subrahmanyam, Sanjai (2005b) Explorations in connected history. Mughals and Franks. Oxford University Press, New Delhi and Oxford.

Terrasa, Antonio (2009) Patrimonios aristocráticos y fornteras político-jurídicas en la Monarquía Católica: los pleitos de la Casa de Pastrana en el iglo XVII. (PhD defended at the EUI).

Tyrrell, Ian (1991) "American exceptionalism in an age of international history" American Historical Review, 96, 4:. 1031-1055.

Tyrrell, Ian (1991b) "Ian Tyrrell response" American Historical Review, 96, 4: 1068-1072.

Va.Aa. (1999) "The Nation and beyond: A special Issue" The Journal of American History. A Special issue, 86, 3.

Vv.Aa. (2007) Cultural Exchanges in Early Modern Europe. Cambridge University Press, Cambridge.

Werner, Michael and Zimmermann, Bénédicte (2002) "Vergleich, Transfer, Verflechtung: der Ansatz der Histoire croisée und die Herausforderung des Transnationalen" Geschichte und Gesellchaft, 28: 607-636.

Werner, Michael and Zimmermann, Bénédicte (2004) "Penser l'histoire croisée: entre empirie et reflexivité". In De la comparation à l'histoire croisée edited by Werber, M. and Zimmermann, B., Seuil, Paris, pp. 15-52.

Yun-Casalilla, Bartolomé (2007) “'Localism', Global History and Transnational History. A Reflection from the Historian of Early Modern Europe". Historisk Tidskrift, 127, 4: 659-678.

Yun-Casalilla, Bartolomé (editor) (2008) Las redes del Imperio. Elites sociales en la articulación del imperio español, 14921714. Marcial Pons, Madrid. 